\title{
Commentary Terlipressin or Europressin?
}

\section{Marc Leone}

Service d'anesthésie et de réanimation, Hôpital Nord, Chemin des Bourrely, 13915 Marseille cedex 20 France

Corresponding author: Marc Leone, marc.leone@ap-hm.fr

Published: 7 October 2009

Critical Care 2009, 13:192 (doi:10.1186/cc8035)

This article is online at http://ccforum.com/content/13/5/192

(c) 2009 BioMed Central Ltd

See related research by Morelli et al., http://ccforum.com/content/13/4/R130

\begin{abstract}
Use of terlipressin in septic shock relies on a series of European studies resulting in a better knowledge of this vasopressive agent. Additional studies demonstrate that this agent appears to have attractive properties when administered properly. In comparison to prior reports, continuous infusion of low-dose terlipressin seems superior when administered to septic animals. For the first time in humans, Morelli and colleagues compared this mode of administration with other vasopressors.
\end{abstract}

In the previous issue of Critical Care, a European group made a new contribution to the terlipressin literature [1]. For the first time, terlipressin, vasopressin, and norepinephrine were compared among patients with septic shock. Because vasopressin is not available in most European countries, terlipressin, a vasopressin analog, was used in patients with norepinephrine-resistant septic shock. Terlipressin is initially indicated in patients with hepatorenal syndrome and bleeding esophageal varices. In 2001, a German group showed its efficacy in endotoxemic sheep [2]. In 2002, a British group treated eight patients with norepinephrine-resistant septic shock by repeated bolus administration of terlipressin [3]. In 2004, studies from France, Spain, and Italy confirmed the feasibility of terlipressin in septic shock [4-6].

Vasopressin and its analogs act on three subtypes of receptors: V1, V2, and V3 [7]. V1 receptors are found on various cells, including vascular smooth muscle cells, causing vasoconstriction. V2 receptors are expressed by kidneycollecting duct cells and mediate water retention. V3 receptors are found on cells within the central nervous system and modulate corticotrophin secretion. In septic shock, treatment is aimed to stimulate $\mathrm{V} 1$ receptors, and the vascular selectivity (V1/V2) of terlipressin is 2.2/1.0 compared with 1.0/1.0 for vasopressin [8].
Initially, terlipressin was used as a substitute for vasopressin. The difference is their pharmacokinetics [7]. The half-life of terlipressin is 6 hours compared with 20 minutes for vasopressin. Because of the prolonged half-life of terlipressin, patients with septic shock received repeated boluses (1 mg) of the drug $[3,4]$. After intravenous injection, terlipressin works as a prodrug that slowly metabolizes to lysinevasopressin and in this way provides prolonged biological effect. Nevertheless, a recent paper shows that terlipressin is not only a prodrug of vasopressin but also a strong vasoconstrictor per se [9]. With regard to vasopressin, terlipressin may by itself have certain specific properties.

Because of its strong vasopressive effects, excessive vasoconstriction and a decrease in cardiac index are associated with bolus injection of terlipressin [3-6]. It was therefore hypothesized that low-dose continuous infusion may reverse sepsis-related systemic arterial hypotension with reduced side effects. In an ovine model, continuous infusion of terlipressin permanently reversed endotoxin-induced systemic arterial hypotension and improved left ventricular stroke work, whereas bolus injections were associated with a decrease in cardiac index and increases in pulmonary resistance [10].

The purpose of the study by Morelli and colleagues [1] was to test this hypothesis in humans. They used a fixed low dose of continuous infusion of terlipressin $(1.3 \mu \mathrm{g} / \mathrm{kg}$ per hour, which is approximately equal to $2 \mathrm{mg} /$ day). This treatment was associated with a reduced norepinephrine infusion rate as compared with a control group. This result was not found in the vasopressin group (0.03 $\mathrm{U} /$ minute). However, as the fixed dosages were compared, this suggests that vasopressin at $0.03 \mathrm{U} /$ minute probably reduces vasoconstriction less than terlipressin at $1.3 \mu \mathrm{g} / \mathrm{kg}$ per hour.

VASST $=$ Vasopressin and Septic Shock Trial. 
The use of invasive monitoring is one of the strengths of the study. As compared with norepinephrine, terlipressin did not impair systemic hemodynamics. However, the persistent low levels of mixed venous oxygen saturation $\left(\mathrm{SvO}_{2}\right)$ in all groups were quite unusual in septic shock. This would indirectly show that the management of these patients did not follow recent published guidelines [11]. The investigators should not be blamed for not following international guidelines, but a local effect may have a role in their findings. At variance, lowdose terlipressin seems to have beneficial effects on regional hemodynamics [12].

One point deserves consideration. Although vasopressin and analogs are recommended in patients with refractory septic shock, the investigators chose to introduce them as first-line treatment. This strategy may in fact be supported by several lines of evidence. In the Vasopressin and Septic Shock Trial (VASST), low-dose vasopressin plus norepinephrine was compared with norepinephrine among patients with septic shock [13]. Although low-dose vasopressin did not reduce overall mortality rates, the mortality rate in patients with less severe septic shock was lower in the vasopressin group than in the norepinephrine group. These results are consistent with findings in isolated arteries, in which the 'beneficial' synergistic effect of low-dose vasopressin (on norepinephrine responsiveness) was preserved in conditions mimicking less severe septic shock but was eliminated in a model of more severe shock [14]. Hence, one can hypothesize that a strategy using an early and multimodal approach to counteract the vascular dysfunction in septic shock may pay off.

Already, we are waiting for the results of the subsequent study, entitled Terlipressin in Septic Shock Trial (TESST-1). This randomized study, a European translation of VASST, was initiated to assess the safety and efficacy of continuous low-dose terlipressin infusion to treat patients with septic shock.

\section{Competing interests}

The author declares that they have no competing interests.

\section{References}

1. Morelli A, Ertmer C, Rehberg S, Lange M, Orecchioni A, Cecchini V, Bachetoni A, D'Alessandro M, Van Aken H, Pietropaoli P, Westphal $\mathrm{M}$ : Continuous terlipressin versus vasopressin infusion in septic shock (TERLIVAP): a randomized, controlled pilot study. Crit Care 2009, 13:R130.

2. Scharte M, Meyer J, Van Aken H, Bone HG: Hemodynamic effects of terlipressin (a synthetic analog of vasopressin) in healthy and endotoxemic sheep. Crit Care Med 2001, 29: 1756-1760.

3. O'Brien A, Clapp L, Singer M: Terlipressin for norepinephrineresistant septic shock. Lancet 2002, 359:1209-1210.

4. Leone M, Albanèse J, Delmas A, Chaabane W, Garnier F, Martin C: Terlipressin in catecholamine-resistant septic shock patients. Shock 2004, 22:314-319.

5. Rodríguez-Núñez A, Fernández-Sanmartín M, Martinón-Torres F, González-Alonso N, Martinón-Sánchez JM: Terlipressin for catecholamine-resistant septic shock in children. Intensive Care Med 2004, 30:477-480.
6. Morelli A, Rocco M, Conti G, Orecchioni A, De Gaetano A, Cortese G, Coluzzi F, Vernaglione E, Pelaia P, Pietropaoli P: Effects of terlipressin on systemic and regional haemodynamics in catecholamine-treated hyperkinetic septic shock. Intensive Care Med 2004, 30:597-604.

7. Delmas A, Leone M, Rousseau S, Albanèse J, Martin C: Clinical review: vasopressin and terlipressin in septic shock patients. Crit Care 2005, 9:212-222.

8. Bernadich C, Bandi JC, Melin P, Bosch J: Effects of F-180, a new selective vasoconstrictor peptide, compared with terlipressin and vasopressin on systemic and splanchnic hemodynamics in a rat model of portal hypertension. Hepatology 1998, 27:351-356.

9. Ryckwaert F, Virsolvy A, Fort A, Murat B, Richard S, Guillon G Colson $\mathrm{PH}$ : Terlipressin, a provasopressin drug exhibits direct vasoconstrictor properties: consequences on heart perfusion and performance. Crit Care Med 2009, 37:876-881.

10. Lange M, Morelli A, Ertmer C, Koehler G, Bröking K, Hucklenbruch C, Bone HG, Van Aken H, Traber DL, Westphal M: Continuous versus bolus infusion of terlipressin in ovine endotoxemia. Shock 2007, 28:623-629.

11. Dellinger RP, Levy MM, Carlet JM, Bion J, Parker MM, Jaeschke R, Reinhart K, Angus DC, Brun-Buisson C, Beale R, Calandra T, Dhainaut JF, Gerlach H, Harvey M, Marini JJ, Marshall J, Ranieri M, Ramsay G, Sevransky J, Thompson BT, Townsend S, Vender JS, Zimmerman JL, Vincent JL: Surviving Sepsis Campaign: international guidelines for management of severe sepsis and septic shock: 2008. Intensive Care Med 2008, 34:17-60.

12. Asfar $P$, Hauser $B$, Iványi Z, Ehrmann U, Kick J, Albicini M, Vogt J, Wachter U, Brückner UB, Radermacher P, Bracht $\mathrm{H}$ : Low-dose terlipressin during long-term hyperdynamic porcine endotoxemia: effects on hepatosplanchnic perfusion, oxygen exchange, and metabolism. Crit Care Med 2005, 33:373-380.

13. Russell JA, Walley KR, Singer J, Gordon AC, Hébert PC, Cooper DJ, Holmes CL, Mehta S, Granton JT, Storms MM, Cook DJ, Presneill JJ, Ayers D; VASST Investigators: Vasopressin versus norepinephrine infusion in patients with septic shock. $N$ Engl J Med 2008, 358:877-887.

14. Leone M, Boyle WA: Decreased vasopressin responsiveness in vasodilatory septic shock-like conditions. Crit Care Med 2006, 34:1126-1130. 